IZA DP No. 5162

Minimum Wages, Labor Market Institutions, and Female Employment and Unemployment: A Cross-Country Analysis

John T. Addison

Orgul Demet Ozturk

September 2010 


\title{
Minimum Wages, Labor Market Institutions, and Female Employment and Unemployment: A Cross-Country Analysis
}

\author{
John T. Addison \\ University of South Carolina \\ and IZA \\ Orgul Demet Ozturk \\ University of South Carolina
}
Discussion Paper No. 5162
September 2010

\author{
IZA \\ P.O. Box 7240 \\ 53072 Bonn \\ Germany \\ Phone: +49-228-3894-0 \\ Fax: +49-228-3894-180 \\ E-mail: iza@iza.org
}

Any opinions expressed here are those of the author(s) and not those of IZA. Research published in this series may include views on policy, but the institute itself takes no institutional policy positions.

The Institute for the Study of Labor (IZA) in Bonn is a local and virtual international research center and a place of communication between science, politics and business. IZA is an independent nonprofit organization supported by Deutsche Post Foundation. The center is associated with the University of Bonn and offers a stimulating research environment through its international network, workshops and conferences, data service, project support, research visits and doctoral program. IZA engages in (i) original and internationally competitive research in all fields of labor economics, (ii) development of policy concepts, and (iii) dissemination of research results and concepts to the interested public.

IZA Discussion Papers often represent preliminary work and are circulated to encourage discussion. Citation of such a paper should account for its provisional character. A revised version may be available directly from the author. 
IZA Discussion Paper No. 5162

September 2010

\section{ABSTRACT \\ Minimum Wages, Labor Market Institutions, and Female Employment and Unemployment: A Cross-Country Analysis}

This paper estimates the effect of minimum wage regulation in 16 OECD countries, 19702008. Our treatment is motivated by Neumark and Wascher's (2004) seminal cross-country study using panel methods to estimate minimum wage effects among teenagers and young adults. Apart from the longer time interval examined here, a major departure of the present study is the focus on prime-age females, a group typically neglected in the component minimum wage literature. Another is our deployment of time-varying policy and institutional regressors. Yet another is our examination of unemployment and participation outcomes in addition to employment effects. We report strong evidence of adverse employment effects among adult females and lower participation, even if the unemployment effects are muted. Although we report some similar findings to Neumark and Wascher as to the role of labor market institutions and policies, we do not observe the same patterns in the institutional data; in particular, we can reject for our target group their finding of stronger disemployment effects in countries with the least regulated markets.

JEL Classification: J20, J38, J48, J58, J88

Keywords: minimum wages, wage fixing machinery, prime-age females, employment, unemployment, participation, cross-section time-series data, OECD countries, labor market flexibility, labor market institutions and policies

Corresponding author:

John T. Addison

Department of Economics

Moore School of Business

University of South Carolina

1705 College Street

Columbia, SC 29208

USA

E-mail: ecceaddi@moore.sc.edu 
There is comparatively little cross-country evidence on the effects of minimum wages on employment. This contrasts with the truly enormous literature on minimum wages. What evidence we have is contained in just two main studies: an early Organisation for Economic Cooperation and Development (OECD) study (1998) looking at the effect of minimum wages on the employment-population ratio of both teenagers and young persons (as well as adults) for a sample of 7(9) OECD countries, 1975-1996, and Neumark and Wascher's (2004) expanded analysis in this Review of 17 OECD nations, 1975-2000, focusing on teenagers and young adults (aged 15 to 24 years) but again looking at the employment-population ratio.

By contrast, the parallel and burgeoning literature on employment protection is largely rooted in cross-country comparisons. And importantly Neumark and Wascher's minimum wage study draws heavily on supplementary arguments from this literature that might be expected either to amplify or moderate the employment consequences of minimum wages (on which more below). ${ }^{1}$ Unlike that literature, however, it does not share the same breadth of outcome indicator, focusing as we have noted on disemployment via the employment-population ratio and eschewing consideration of unemployment, labor-force participation, and other indicators (e.g. hours).

In the present treatment, while further updating the period of analysis, we also seek to link the minimum wage and employment protection literatures. But our target group differs critically from that traditionally examined in the two literatures and especially the minimum wage literature. That is, we will look at the labor market effects of minimum wages on workers other than teenagers and youths that are also at risk from wage minima, namely females aged 25 to 54 years. To the extent that this group of prime-age females includes low-productivity labor reflecting their historically lower human capital accumulation due to interruptions in labor market experience and more limited access to education and training - the bite of minimum wages can also be expected to be material, and presumably more so in developing nations (Ozturk, 2006). The impact of minimum wages may be underscored by the higher-valued outside options of females, which in turn suggests that a wider range of outcomes other than disemployment be considered, to include participation. Furthermore, the existence of youth subminima that have been found to ameliorate the adverse consequences of minimum wages among that target group might be expected to have just the opposite effect among adult females. 
'Policy complementarities' invoked by the wider literature are also examined. In particular, we examine all the labor market institutions considered by Neumark and Wascher (2004) in their innovative analysis. As an additional refinement, we introduce a time-varying measure of the key employment protection argument. Indeed, most of our variables are timevarying with the exception of labor standards and the variables identifying the process in which minimum wages are set. ${ }^{2}$

\section{Previous Research}

As mentioned earlier, despite the massive amount of research on the employment and other consequences of minimum wages (see Neumark and Wascher, 2007) there is scant crosscountry analysis exploiting the tremendous variation in minimum wages by nation state. ${ }^{3}$ As further noted, the two principal analyses using panel data for industrialized nations are those of the OECD (1998) and Card and Neumark (2004).

The OECD study looks at the effect of minimum wages on the employment of teenagers, young adults, and prime-age adults for a small sample of countries, 1975-1996. ${ }^{4}$ The countries are Belgium, Canada, France, Greece, Japan, the Netherlands, Portugal, Spain, and the United States. However, for the gender analysis, the sample is reduced to seven counties because of the lack of adequate series of average wages for Portugal and Spain.

The regressions follow the state-level panel data specifications now standard in the U.S. minimum wage literature. The dependent variable for the full sample was the employmentpopulation ratio for teenagers aged 15 to 19 years, youths aged 20 to 24 years, and adults aged 25 to 54 years. For the reduced seven-country sample, separate male and female subsamples of each group were used. The key minimum wage ratio was calculated separately for each group using the relevant average wage and allowing for youth rates where applicable. The employment population ratio was regressed on the ratio of minimum to median wages with controls for the business cycle (the prime-age male unemployment rate and/or the output gap), different institutional features (not including employment protection), country trend effects, and fixed country effects.

It was found that increases in the minimum wage measure had a negative impact on teenage employment across all specifications (albeit in some instances attendant upon the exclusion of Portugal and Spain). For the full (partial) sample of countries, in the authors' 
preferred specifications - with corrections for first-order autocorrelation for the error terms and heteroscedasticity across countries - a 10 percent increase in the minimum wage was associated with a fall in teenage employment of between 1.5 and 2 (2.7 and 4.1) percent. On the other hand, for young adults aged 20 to 24 years and for adult prime age males and females the elasticities were seldom statistically significant. ${ }^{5}$

The OECD analysis does not consider the role of labor market institutions/policies other than union density, the unemployment insurance (UI) replacement rate, and non-wage labor costs as a proportion of total costs/the tax wedge - and it does not report the respective coefficient estimates, merely a summary of the estimated employment elasticities (a sample of which are given above). But, as is well known, empirical analysis of the consequences of employment protection in particular has mushroomed since Lazear's (1990) pioneering study. Other institutions examined in addition to employment protection have included active labor market policies, coordination in collective bargaining, and labor standards (e.g. Scarpetta 1996; Nickell and Layard 1999). More recent developments have included potential interactions between institutions and between institutions and economic shocks (e.g. Addison and Teixeira 2003; Nickell, Nunziata and Ochel 2005). ${ }^{6}$ And yet more recent innovations have included the role of product market and business regulation, size of government, quality of industrial relations, and even religion. Unlike the minimum wage literature, most such analyses have focused on crosscountry differences.

The study by Neumark and Wascher (2004) is notable in attempting to bridge the gap between these two literatures, even if minimum wages have sometimes figured in the armory of labor market policies investigated in aggregate. Specifically, Neumark and Wascher investigate the effect of minimum wages on teenage and youth employment - again, the employmentpopulation ratio - for seventeen countries over the (maximum) sample period 1976-2000. These countries include, in addition to those examined by the OECD (1998), Italy, Australia, Germany, Denmark, Sweden, Luxembourg, New Zealand, and the United Kingdom.

The dependent variable is the employment-population ratio for the group concerned, although the minimum wage argument - the ratio of the minimum wage to the average wage uses the adult minimum wage in the numerator and the all-worker average in the denominator workers. Neumark and Wascher's basic equation regresses the employment measure on a oneyear lag of the minimum-to-average-wage ratio plus aggregate labor market and demographic 
controls. The authors provide results for a simple OLS specification, fixed effect models with and without controls for year effects and time trends, and a dynamic version of the model via the inclusion of a lagged dependent variable and estimated using the GMM technique. In all cases, including the latter, they obtain well-determined negative coefficient estimates for the minimum wage variable. The estimated minimum wage elasticities range from -0.13 to -0.28 for young adults and from -0.09 to -0.31 in the case of teenagers.

The authors then augment their basic estimating equations with variables representing (a) characteristics of the minimum wage system, and (b) other labor market policies and institutions. Under (a) they consider the role of a bargained minimum wage (the omitted category is statutory minimum wage determination), a system with subnational wage minima, and a system with youth subminima. Abstracting from the independent effects of the different types of minimum wage machinery and focusing on the interaction terms from the authors' fixed effect and GMM specifications, it is reported that bargained minima are associated with a smaller negative employment impact of minimum wages and conversely where there are industry or geographic wage floors. As expected, youth subminima reduce the adverse effects of minimum wages on young persons' employment, especially in the case of teenagers.

Under (b) the institutions considered are labor standards, employment protection, active labor market policies, the unemployment insurance (UI) replacement rate, and union density. ${ }^{7}$ Again focusing on results from the preferred fixed effect and GMM specifications, the authors find evidence of certain complementarities. Thus, more restrictive labor standards and higher union density tend to exacerbate the disemployment effects of minimum wages, while stricter employment protection and active labor market policies appear to have the opposite effect. Of the institutional variables, only UI replacement rates appear to bear no relation to minimum wages - even if their independent effect is seemingly to reduce employment.

In a final application, Neumark and Wascher seek to erect a typology of minimum wage countries and investigate their component minimum wage elasticities. The categories are fourfold: high employment protection/active labor market policies in combination with either high or low labor standards and low employment protection/active labor market policies again in combination with either high or low labor standards. It emerges that negative employment minimum wage effects are strongest for the group of countries having the least regulation, namely Canada, Japan, the United States and the United Kingdom. 


\section{Theoretical Backdrop and Econometric Specification}

The theoretical model in this paper is implicit. It is in the spirit of Cahuc and Zylberberg (1999) and Coe and Snower (1997). ${ }^{8}$ Cahuc and Zylberberg offer a dynamic search and matching model with wage negotiations and employment protection (viz. severance payments and limitations on dismissals), and introduce minimum wage setting into this framework to study its impact on job creation and job destruction. Their model implies that employment protection may strongly elevate unemployment of lower skilled workers when the minimum wage is high but have little impact where the minimum wage is low (or when wages are flexible). For their part, Coe and Snower develop a model of policy complementarities and show that policies/institutions that affect the bargaining power of incumbent employees, or that influence the search behavior of the unemployed, or that influence barriers to job creation can have complementary effects on unemployment such that minimum-wage like measures that cost jobs can be magnified or ameliorated according to the restrictiveness of the ruling labor market environment. Both models, then, capture the interaction of minimum wages with labor market rigidities and labor force characteristics, and imply that minima will be less disruptive when policies are less rigid.

The more obvious component of the model is the extent to which the minimum wage is effective. When the minimum wage is binding, the demand curve determines the level of employment for the given minimum wage; otherwise, equilibrium employment is a function of both demand and supply. We do not model the determinants of the probability that the minimum wage will bind (see, inter al., Addison, Blackburn, and Cotti, 2010) but rather attempt to capture its bite here by expressing the minimum wage as a ratio of median wage. ${ }^{9}$ (Since the latter argument is only available for all workers, we supplement it with a measure of the gender gap on the reasoning that the larger the gap between males and females, the more likely the latter to be adversely impacted by hikes in the minimum wage. We also experimented with a measure of the disparity in female earnings, as proxied by the 90:10 percentile spread, although this measure was available for a reduced sample of countries. Use of the minimum to median wage ratio also reduces the bias arising from the correlation between minimum wage levels and macroeconomic events affecting minimum wage levels.

Our econometric specification is as follows:

$$
\begin{aligned}
& Y_{i t}=\alpha_{i}+\lambda_{t}+\theta_{i} t+\beta M W_{i t-1}+\delta X_{i t}+\gamma Z_{i}+\varphi M W_{i t-1} X_{i t}+\zeta M W_{i t-1} Z_{i}+\varepsilon_{i t} \\
& i=1, \ldots, I=16 ; t=1, \ldots, T=39
\end{aligned}
$$


where $\mathrm{Y}_{\mathrm{it}}$ is alternately the female employment rate, unemployment rate, and participation rate in country $i$ and time $t ;{ }^{10} \mathrm{MW}_{\mathrm{it}-1}$ is the minimum to median wage ratio; $\mathrm{X}_{\mathrm{it}}$ and $\mathrm{Z}_{\mathrm{i}}$ are the timevarying and time-invariant supply, demand, and institutional arguments, respectively; $\alpha_{\mathrm{i}}$ indexes fixed country effects and $\lambda_{\mathrm{t}}$ fixed year effects; $\theta_{\mathrm{i}}$ captures the time trends in the outcome indicator for country i; and $\varepsilon_{i t}$ is an error term. The data cover 16 countries and the time interval 1970 to 2008. The time-varying arguments in the vector $X_{i t}$ comprise our three base regressors (the adult male unemployment rate, the fertility rate, and the wage gap) plus four institutional regressors (employment protection, union density, the UI replacement rate, and active labor market policies). The time-invariant arguments in the vector $\mathrm{Z}_{\mathrm{i}}$, are all institutional: three measures describing the minimum wage fixing machinery (bargained versus statutorily determined, and presence of youth and subnational minima) along with a labor standards index. The institutional components of the vectors $\mathrm{X}_{\mathrm{it}}$ and $\mathrm{Z}_{\mathrm{i}}$ are also interacted with the lagged minimum wage measure.

OLS and fixed effect versions of equation (1) were run. Additionally, we estimated our preferred dynamic version of the model by including the relevant lagged dependent variable as a regressor. We used the Generalized Method of Moments (GMM) technique developed by Arellano and Bond (1981) to estimate the dynamic model.

\section{Data}

The data used in this inquiry are gathered from OECD online databases and published resources, and from the CEP-OECD Institutions Data Set (Nickell, 2006). The data in question cover employment to population ratios, unemployment rates, labor force participation rates, adult male unemployment rates (as a business cycle control), minimum wages and minimum wage rules, measures of labor market rigidity, the gender wage gap, and the fertility rate. OECD data on minimum wages are available where a national minimum wage is set by statute or by a national collective bargaining agreement. For countries where no national minimum exists, but where industry- or occupation-specific minima are set by legislation or collective bargaining agreements, we use summary estimates constructed by Dolado et al. (1996) as our base measure,

following Neumark and Washer (2004). ${ }^{11}$ These estimates relate the minimum wage to average wages whereas the corresponding OECD values are based on the minimum to median wage ratio.

(Table 1 near here) 
Most OECD countries have some sort of minimum wage policy. Table 1 provides information on these minima, as well as the machinery of minimum wage determination, for those countries for which we have been able to assemble consistent data on all variables. As is immediately evident, the countries differ not only in terms of the relative level of minimum wages - and hence in the potential bite of minimum wages - but also in rule setting. The first two columns of the table give the relative values of the minimum wage at two points in time, namely 1970 and 2008 (unless otherwise stated). For most countries, minimum wage to median wage ratios declined through time; the principal exceptions being France and the United Kingdom. European countries generally have higher relative values of the minimum wage than their non-European counterparts, including the United States. This empirical regularity has of course been noted in the wider literature and, taken in conjunction with the greater degree of labor market regulation obtaining in Europe, cited as a principal cause of that region's high unemployment rates (e.g. Siebert, 1997)

The last three columns of Table 1 summarize the minimum wage rules. The first indicates how minimum wages are determined. Here 'yes' signifies that the minimum wage is negotiated; that is, set via bipartite or tripartite negotiations; 'no' signifies the wage is set by statute. For the United Kingdom we observe a switch in regimes from bargained (wages councils) to statutory over the sample period. The fourth column shows whether the minimum wage is national in scope or instead varies across industries or regions; for example, in Japan, the minimum wage varies across prefectures, whereas in the United States each state can set its own minimum exceeding the national. ${ }^{12}$ For our sample of countries, regional and industry variation is more common than a unified national minimum. The final column of the table indicates whether there are any subminimum wages for younger persons and, if so, the age at which they apply. Some countries are difficult to classify in this regard and we were ultimately guided by Neumark and Wascher (2004:234) in treating France, Germany, Italy, and the United States as having no youth subminima.

\section{(Table 2a near here)}

There are also significant cross-country differences in the extent of labor market regulation, socio-demographics, and labor market activity, as charted in Tables 2a and 2b. Beginning with the outcome indicators in Table 2a, although the observed changes in female labor force participation rates are consistent with the general worldwide trend (increasing in all 
of the countries over the thirty-nine year period), participation rates vary sometimes quite considerably. Thus, at any point in time, Italy, and Spain have significantly lower participation rates when compared with other countries, and especially the Nordic nations of Finland, Denmark, Norway and Sweden. Participation rates are one of the key margins investigated in the present treatment because minimum wages, and other rigidities, may inhibit the low productivity workers either from entering the market in the first place or actively seeking employment once unemployed.

\section{(Table 2a near here)}

Employment to population ratios rose significantly in all countries other than Sweden and Finland, where the observed changes were modest. Although employment rates do vary markedly across countries - from just 40.3 percent in Spain to 80.6 percent in Sweden - it is unemployment rates that show the greatest variance over the sample period. Even if by the early 2000s unemployment rates were close to their 1980 values, most European countries experienced very high unemployment in the intervening years. And the female unemployment rate actually rose from 1.7 percent in 1970 to 6.6 percent in 2009.

In general, fertility rates declined significantly over the sample period; the exceptions were Norway, the United Kingdom, the Netherlands, and Sweden. In the 1980s the fertility rate averaged 2.5 children per woman cross all OECD countries. By 2004 this average had declined to 1.8 children (and was even as low as 1.6 children during the late 1990s). Child birth is the main reason for interruptions in a woman's work life and caring for young children either keeps women off the market or directs them to careers that permit flexibility to balance work and family. Such interruptions and career choices imply lower wages for women vis-à-vis men of the same age and education.

The wage gap given in the last column of Table $2 \mathrm{a}$ is the difference between median male and female wages expressed as a percentage of the median male wage. This variable was included to capture the existence of gender differences in occupational choice and education that might be expected to affect the bite of minimum wages in the case of females. Historically, females have had lower rates of labor market attachment and have tended to concentrate in lower-paying occupations, both of which tendencies make them susceptible to minimum wageinduced disemployment. As can be seen from the table, the wage gap averaged 22.5 percent over the period, ranging from 12.2 percent in Belgium to 37.9 percent in Japan. ${ }^{13}$ 
(Table 2b near here)

Finally, there are striking differences in the labor market conditions and institutions of countries in the data, which can potentially shape the manner and the intensity with which minimum wages affect the outcome indicators. Thus, for example, one can easily see that the employment effects of minimum wages might be amplified if the country in question places restrictions on hours adjustment or on the overall remuneration package offered to employees, thereby making contracts less flexible. However, if there are also institutions in place that help the unemployed locate jobs, the frictions resulting from the impedimenta of minimum wage changes may be considerably attenuated. For these reasons, we include in the model measures of labor standards, of the strictness of employment protection laws, of the extent of active labor market policies, the generosity of UI replacement rates, and the degree of unionization rates. Table $2 \mathrm{~b}$ provides the descriptive statistics.

\section{Findings}

\section{Basic Regression Results}

Our initial cet. par. results are provided in Table 3 for our three outcome indicators: the adult female employment to population ratio, the adult female unemployment rate and the adult female labor force participation rate. Three sets of results are provided for each indicator: OLS, fixed effects, and finally Generalized Method of Moments to estimate the dynamic version of the model(s).

\section{(Table 3 near here)}

Beginning with the findings for the employment to population ratio, the results in the first column are for a specification that excludes fixed country effects but otherwise accounts for fixed year effects and country trends. The point estimate for the lagged minimum wage variable for this OLS specification indicates a well-determined disemployment effect of the minimum wage variable. The estimated elasticity - computed as the coefficient on the minimum wage variable plus each of the coefficients on the interaction terms - reported later in the table indicates that a 10 percent increase in the minimum wage variable is associated with a 4.6 percent fall in female employment. This is of course a strong estimate for developed nations.

With respect to independent effect of the remaining regressors, the coefficient estimate for the adult male unemployment rate (our proxy for demand conditions) is negatively related to 
female employment. The estimated effect of the wage gap variable is also negative, indicating that female employment rates are lower, the lower female relative wages; rather more importantly, however, in interaction with minimum wages, a greater wage gap in favor of males appears to be an indicator of the bite of minimum wages. That said, in neither case are the coefficient estimates statistically significant. Finally, and again as expected, greater family size by itself is associated with reduced employment, although on this occasion the interaction term is positive and also well determined perhaps suggesting that the effects of family size may be different among minimum wage earners and among those earning close to the minimum wage.

Introducing fixed country effects in the fixed effects specification, given in second column of the table, materially influences the size of the coefficient estimate for the minimum wave variable, more than halving its absolute magnitude and suggesting that a sizable part of the effect obtained earlier reflects country-specific factors. Note, too, that the much-reduced estimated elasticity is on this occasion no longer statistically significant. The Hausman test strongly rejects the null that the fixed country effects can be omitted from the specification. The coefficient estimates for adult male unemployment and the wage gap are little altered vis-à-vis the OLS specification in the first column, but note that the interaction term with the minimum wage measure is now statistically significant giving further credence to the wage-bite argument. Fertility rates are no longer statistically significant either independently or in interaction with minimum wages.

Finally, the GMM estimates in the third column serve to further reduce the point estimate of the minimum wage variable and the absolute value of the computed elasticity which, however, regains its statistical significance. Among other findings from the dynamic model are of course the highly significant coefficient estimate for the lagged dependent variable, and the demand variable (the adult male unemployment rate). The wage gap coefficients estimates are reduced in absolute magnitude and while statistically significant are now only marginally so. As in the fixed effects specification, fertility is nowhere statically significant. Recall that the inclusion of the lagged employment rate can also be interpreted as helping to distinguish between the short-run and long-run effects of the minimum wage on employment. On these estimates, -0.056 is the short-run coefficient and $-0.179(=.056 /(1-.687))$ is the long-run coefficient.

The results in the next three columns of the table switch to the unemployment outcome. We expect less from these regressions since unemployment is not the inevitable consequence of 
disemployment; reduced labor force participation (see below) being an obvious alternative. These expectations are not borne out in our preferred specification, however, where the positive minimum wage coefficient is statistically significant at the 5 percent level. Not surprisingly, the inverse demand indicator (now a subcomponent if the dependent variable) is positively associated with female unemployment. More interestingly, the wage gap in interaction with the minimum wage arguments is positively associated with female unemployment in both the fixed effect and GMM specifications.

The participation rate equations shown in the last three columns of Table 3 all confirm that disemployment even if it is not always linked to higher unemployment appears to have a counterpart in lowered female labor force participation. The minimum wage elasticities with respect to participation are also in most cases statistically significant. The most interesting other result is again the performance of the wage gap variable. Although typically poorly determined as an independent influence, in interaction with minimum wages it again seems to suggest that where minimum wages bite most - as indexed by a higher wage gap - the negative effects on participation are strongest. The coefficient estimates for this interaction term are negative throughout, and statistically significant in the fixed effects and GMM specifications.

\section{The Augmented Model}

We now allow for differences in minimum wage systems across countries and for other labor market policies and institutions. As far as the minimum wage is concerned, we consider the method used to set minimum wages (whether it was bargained, as opposed to being statutorily determined), whether provision is made for a youth subminimum, and whether wage floors vary across regions/industries. ${ }^{14}$ Apart from the contribution of the machinery of minimum wage setting, we examine the role of more encompassing employment protection, higher labor standards, and greater union density, as well as more generous UI systems and more comprehensive active labor market policies. Note that with the exception of the labor standards argument all of these variables are time varying rather than fixed as in Neumark and Wascher.

(Table 4 near here)

Results of the augmented model are given in Table 4. Beginning with the key employment dependent variable, the OLS results suggest that bargained minimum wages as opposed to statutorily-determined minima do not facilitate female employment. Although the 
independent effect of bargained minima is positive, the interaction term is negative and larger in absolute magnitude. Whatever the supposed flexibility introduced by such minimum wage systems for other groups of workers, this decidedly does not carry over to adult females; if anything, any such effect is generated by the presence of subnational minimum rates. Unexpectedly, the presence of a youth minimum in conjunction with the minimum wage argument is associated with significantly higher female employment rates. As far as the other institutions are concerned, more generous employment protection (though not higher union density or labor standards) is seemingly independently injurious to adult female employment but in association with the minimum wage argument appears not just to soften but overturn such implied employment losses. On the other hand, taken in conjunction with the minimum wage, higher labor standards are associated with disemployment. It is hard to detect any beneficial independent impact of the other two policies. Finally, the performance of the basic arguments examined earlier is largely strengthened. Most notably, in interaction with the minimum wage argument, the adverse role of the wage gap is strengthened.

Our preferred estimates are to be found in the next two columns of the table. The independent influences of employment protection, union density, and the UI replacement rate are all negative but with the exception of the latter generally not statistically significant, while the directional influence of the basic variables is confirmed. More noteworthy is the strengthening of the coefficient estimate for the minimum wage argument, on which more below. The interactions of the minimum wage argument with the wage gap and the labor market institutions/policies are also of interest. The former association is again strong and strengthens for the GMM specification (compare Table 3); the results again suggesting that the lower the female relative wage, the bigger the bite of the minimum wage. As far as the institutions are concerned, observe that in both cases more embracing employment protection is associated with higher female rates but in neither case is the coefficient estimate statistically significant. For their part, higher labor standards still act as a drag on female employment. Although union density is still nowhere statistically significant, the effects of more generous UI replacement rates are now positive and well determined. And active labor market policies gain traction. The benefits for adult female employment rates of a youth subminimum are seemingly not an artifact of the data and the seeming detriment of a bargained minimum wage is underscored. For both specifications, the presence of different wage floors by industry and region seems to reduce the sting of minimum 
wages. But of all the findings, most notable is the strengthening of the estimated elasticity of female employment to the minimum wage. The estimates range from -0.689 in the first column of the table through -0.209 in the second column to -0.174 in the third column. Each exceeds in absolute magnitude the estimates earlier reported in Table 3.

Turning next to the unemployment results, it can be seen that the point estimates for the lagged minimum to median wage ratio argument are nowhere statistically significant. Focusing on the interaction terms, therefore, the findings for the institutional arguments are with the exception of labor standards broadly consistent with the employment results (i.e. mostly producing sign reversals). This is most notably the case for those variables indexing differences in minimum wage systems and employment protection. Interestingly, there is no suggestion that more generous UI replacement rates increase unemployment or that active labor market policies reduce it.

Next consider the results for female labor force participation rates contained in the last three columns of Table 4. These in many cases simply parallel the results for employment rates. Thus, the strong effects of minimum wages on participation match those for employment while help explaining the ambiguous results for unemployment. Again note that, in conjunction with the minimum wage argument, a youth subminimum, wage floors that vary across industries or regions (in the GMM specification), and more generous unemployment benefits (again in the GMM specification) seem to advance female participation, while a bargained minimum wage, a greater wage gap, and higher labor standards detract from participation.

(Table 5 near here)

As a final exercise, we investigate differences in minimum wage effects across countries. The individual country minimum wage elasticities are reported in Table 5. The estimates in question are based on the GMM specifications given in the third, sixth, and ninth columns of Table 4. The elasticities are calculated as the coefficient on the minimum wage variable plus each of the coefficients on the interaction terms multiplied by the minimum wage rule dummies and the standardized values of the policy variables/wage gap/fertility rates for that country. Each country elasticity estimate is statistically significant at conventional levels. ${ }^{15}$

The minimum wage elasticities with respect to employment range from - 0.055 in the case of the Netherlands to -0.420 for Italy. The corresponding range for the minimum wage participation elasticity is -0.056 (for Ireland) to -0.339 (Italy). These results imply material 
disemployment effects and they are not confined to employment and participation. That said, the minimum wage unemployment elasticities are smaller in absolute terms, although with one exception they are positive and in almost all cases statistically significant. In other words, minimum wages also spill over into female unemployment. To our knowledge these are the strongest and most consistent indications of the adverse consequences of minimum wages for adult females to have been reported in the literature.

(Tables 6 and 7 near here)

The next issue concerns combinations of policies. As we have seen, Neumark and Wascher (2004: 242-3) were able to detect certain patterns in the data; most notable of which was their finding that the disemployment effects of minimum wages were strongest in those countries (Canada, Japan, the United States, and the United Kingdom) with the least regulated markets. In our framework of time-varying regressors, identification of individual countries with set regimes is not straightforward. We first followed Neumark and Wascher's methodology and grouped our countries with respect to degree of market regulation using an average value for the policy indicators and by creating a joint ranking for employment protection and active labor market policies. As is evident from Table 6, we cannot replicate their results for prime-age females. Indeed, if anything, the suggestion is the least regulated markets produce the best outcomes for women.

However, it is manifestly the case that the patterns are by no means consistent for all countries in these groups, pointing to the role of other factors in explaining the differences. Moreover, with our time-varying regressors, countries move in their rankings over the years, making it hard to characterize countries as populating a unique cluster. In Table 7, therefore, we allow each country to be classified by its yearly status by policy dimension. We can see from this table that in highly regulated countries, especially in circumstances where the wage gap is high (where women are less productive or concentrated in low-paying industries), and where fertility rates are also high (implying lesser job experience) minimum wages have the highest collateral damage to female employment and participation. In short, policy parameters alone cannot explain elasticities in a cohesive manner. Other country characteristics play a more crucial role in explaining female labor market activity.

The bottom line is that despite the results of our regression analysis sharing a key commonality with the study of Neumark and Wascher, there is little evidence of similar patterns 
of elasticities in our data. This is not unexpected given the time-varying nature of our regressors and the different demographic group studied.

\section{Concluding Remarks}

This is one of only a handful of studies to have investigated the sensitivity of female employment to the minimum wage and almost the only one to exploit a pooled cross-section time-series data set. Our study was motivated in no small part by Neumark and Wascher's seminal study of the sensitivity of teenage and youth unemployment to minimum wages, the innovation here residing in their analysis of a cross-country panel of data rather than the target group selected. In this regard we were also struck by the authors' caveat that, by using the adult minimum wage in constructing the minimum wage ratio, they had "overstated the relevant (or 'effective') minimum wage for the age groups under study ...” (Hence their use of a youth subminimum in their first set of extended regressions.). In our study, use of the adult minimum wage raises no such difficulties of interpretation; although our understanding of minimum wage effects is enhanced by the inclusion of a gender wage gap argument. And indeed we found consistent evidence that increases in minimum wages translated into lower female employment and participation rates, even if the unemployment results were not transparent in this regard. On the other hand, we were frankly surprised by the failure of the presence of youth subminima to strengthen the minimum wage effect. Seemingly, if Neumark and Wascher's results carry over to female teenagers and youth in the present data set, such groups would be adjudged gross complements with adult females. However, another possibility is of course that the substitution possibilities are poorly proxied by this argument.

There were also some interesting commonalities having to do with the role of labor standards and to a lesser extent UI replacement rates. Yet the dominant result of the present inquiry is and remains the finding of consistent disemployment effects of the minimum wages for adult females. Our preferred estimates of the elasticity of the employment-to-population ratio with respect to the minimum wage ranged from -0.051 to -0.103 in the basic model and from 0.174 to -0.209 in the augmented model.

Finally, our data do not permit such a tidy pattern or configuration of nations as reported by Neumark and Wascher for youths and teenagers of both genders. We do not find any obvious 
alignment of labor market institutions and policies. If anything, the institutional patterns we detect are even the reverse of those reported by Neumark and Wascher. 


\section{Endnotes}

1. This is an oversimplification to the extent that the existence of a minimum wage is sometimes present in the employment protection literature, where it is aggregated in a general measure of labor market (in)flexibility.

2. We also considered the role of other labor market institutional and policy variables such as the tax wedge and the degree of coordination in collective bargaining, as well as some other mainstream arguments such as the output-gap. These proved mostly statistically insignificant and are not further discussed here.

3. Although for meta-analyses, see Card and Kruger (1995); Boockmann (2010).

4. Note that the OECD study ranges further afield to investigate the impact of minimum wages on poverty and the income distribution and on wages and the wage distribution.

5. Among teenagers, female elasticities always exceeded those of males but no such gender pattern obtained in the cases of youths and adults.

6. Coe and Snower (1997), provide the theoretical basis for expecting complementarities between the various labor market policies, to include the minimum wage.

7. The authors exclude from these regressions the other institutional arrangements concerning the mechanics of minimum wage setting considered earlier.

8. See also Kahn (2010).

9. On the superiority of the minimum wage as a ratio of the median vis-à-vis the average wage in international comparisons, see OECD (1998: 38).

10. We also examined average hours worked, although female hours were available for only eight countries, a much reduced sample.

11. We are indebted to David Neumark and William Wascher for supplying us with the data they used in their 2004 study, some of which is used here.

12. The 'new minimum wage research' in the United States has used this geographic variation to help identify employment effects, albeit in quite different ways (cf. Neumark and Wascher 1992; Card and Krueger 1994).

13. We also included a wage measure that captures the distribution of female wages, namely the difference between the $90^{\text {th }}$ and $10^{\text {th }}$ percentile of the female wage distribution. The results are entirely consistent with those reported for the minimum wage and are available from the authors upon request. 
14. As noted by Neumark and Wascher (2004: note 18), the classification of minimum wage systems is inevitably open to some discretion, especially with respect to youth subminima. We follow their convention in treating the cases of Italy, France, Germany and the United States, where there is some such limited wage differentiation as having no such differentiation. On the broader question of Germany, where the differentiation stems from its famous apprenticeship system, there is of course the very much wider issue of whether that nation is properly classified as having minimum wages at all - at least prior to the recent posted workers act and latterly the introduction of minima for individual sectors such waste disposal. As a practical matter, the exclusion of Germany did not materially affect any of the major findings reported below or earlier; full results are available from the authors upon request.

15. We also estimated the corresponding minimum wage elasticities for the fixed effect specifications given in the second, fifth, and eighth columns of Table 4. The elasticities were somewhat larger than those reported in Table 5 and all were well determined. The results are available from the authors upon request. 
Table 1. Minimum Wage Levels and Rules

\begin{tabular}{|c|c|c|c|c|c|c|c|c|}
\hline \multirow{3}{*}{$\begin{array}{l}\text { Country } \\
\text { Australia }\end{array}$} & \multicolumn{2}{|c|}{$\begin{array}{l}\text { Minimum to Median } \\
\text { Wage Ratio }\end{array}$} & \multirow{2}{*}{\multicolumn{2}{|c|}{ Bargained Minimum Wage }} & \multirow{2}{*}{\multicolumn{2}{|c|}{$\begin{array}{l}\text { Presence of Subnational } \\
\text { Minimum Wages }\end{array}$}} & \multirow{2}{*}{\multicolumn{2}{|c|}{$\begin{array}{l}\text { Presence of Youth } \\
\text { Subminimum }\end{array}$}} \\
\hline & \multirow{2}{*}{$\begin{array}{c}\text { First } \\
\text { Observation } \\
0.65 \text { (1985) }\end{array}$} & \multirow{2}{*}{$\begin{array}{c}\begin{array}{c}\text { Last } \\
\text { Observation }\end{array} \\
0.52\end{array}$} & & & & & & \\
\hline & & & no & & no & & yes & $<21$ \\
\hline Belgium & $0.54(1975)$ & 0.50 & yes & & no & & yes & $<21$ \\
\hline Canada & 0.48 & 0.41 & no & & yes & Province & no & \\
\hline Denmark & 0.55 & $0.54(1994)$ & yes & & yes & Industry & yes & $<18$ \\
\hline Finland & $0.52(1993)$ & $0.52(1993)$ & yes & & yes & Industry & yes & $<18$ \\
\hline France & 0.42 & 0.62 & no & & no & & no & limited \\
\hline Germany & 0.57 & $0.58(1994)$ & yes & & yes & Industry & no & some \\
\hline Ireland & $0.67(2000)$ & 0.52 & no & & no & & yes & $<18$ \\
\hline Italy & $0.78(1976)$ & $0.71(1991)$ & yes & & yes & Industry & no & some \\
\hline Japan & $0.78(1975)$ & 0.34 & no & & yes & Prefecture & no & \\
\hline Netherlands & 0.58 & 0.42 & no & & no & & yes & $<23$ \\
\hline New Zealand & 0.60 & 0.59 & no & & no & & yes & $<20$ \\
\hline Spain & 0.70 & 0.44 & no & & no & & yes & $<18$ \\
\hline Sweden & 0.53 (1975) & 0.51 & yes & & yes & Industry & yes & $<24$ \\
\hline United Kingdom & 0.365 & 0.46 & yes/no & $\begin{array}{l}\text { Wages Councils (up to 1993); } \\
\text { Statute (after 1999) }\end{array}$ & yes /no & Industry & yes & $<21$ \\
\hline United States & 0.49 & 0.34 & no & & yes & State & no & Limited \\
\hline
\end{tabular}

Note: First and last observations of minimum to median wage ratio are for 1970 and 2008, respectively, unless otherwise noted.

Sources: Minimum to median wage ratios are obtained from OECD online database for all countries and years except for Denmark, Germany, Italy, Sweden, and the United Kingdom (before 1993). For these countries, we use summary estimates constructed by Dolado et al. (1996) as our base measure following Neumark and Washer (2004). Minimum wage rules are taken from Neumark and Washer (2004: 228) and the ILO TRAVAIL Legal database. 
Table 2a. Means (and Standard Deviations) of the Labor Market Outcomes and Gender Variables

\begin{tabular}{|c|c|c|c|c|c|}
\hline Country & $\begin{array}{l}\text { Employment to } \\
\text { Population Ratio }\end{array}$ & $\begin{array}{c}\text { Labor Force } \\
\text { Participation Rate }\end{array}$ & Unemployment & Fertility & Wage Gap \\
\hline Australia & $0.586(0.094)$ & $0.619(0.101)$ & $0.052(0.015)$ & $1.969(0.295)$ & $0.170(0.026)$ \\
\hline Belgium & $0.609(0.087)$ & $0.678(0.077)$ & $0.104(0.031)$ & $1.709(0.17)$ & $0.122(0.031)$ \\
\hline Canada & $0.672(0.087)$ & $0.726(0.088)$ & $0.075(0.015)$ & 1.679 (0.174) & $0.271(0.129)$ \\
\hline Denmark & $0.792(0.023)$ & $0.848(0.018)$ & $0.066(0.021)$ & $1.719(0.171)$ & $0.132(0.012)$ \\
\hline Finland & $0.785(0.040)$ & $0.831(0.042)$ & $0.055(0.035)$ & $1.727(0.086)$ & $0.227(0.026)$ \\
\hline France & $0.643(0.076)$ & $0.705(0.098)$ & $0.084(0.033)$ & 1.903 (0.203) & $0.164(0.058)$ \\
\hline Germany & $0.611(0.091)$ & $0.657(0.112)$ & $0.066(0.027)$ & $1.442(0.163)$ & $0.252(0.022)$ \\
\hline Ireland & $0.469(0.162)$ & $0.509(0.161)$ & $0.084(0.051)$ & $2.523(0.702)$ & $0.19(0.045)$ \\
\hline Italy & $0.444(0.097)$ & $0.490(0.117)$ & $0.088(0.039)$ & $1.561(0.394)$ & $0.166(0.011)$ \\
\hline Japan & $0.603(0.050)$ & $0.621(0.058)$ & $0.028(0.012)$ & $1.619(0.272)$ & $0.379(0.038)$ \\
\hline Netherlands & $0.518(0.184)$ & $0.548(0.193)$ & $0.054(0.033)$ & $1.682(0.223)$ & $0.237(0.046)$ \\
\hline New Zealand & $0.691(0.036)$ & $0.726(0.031)$ & $0.048(0.014)$ & $2.152(0.330)$ & $0.162(0.069)$ \\
\hline Spain & $0.403(0.131)$ & $0.479(0.164)$ & $0.145(0.085)$ & $1.76590 .630)$ & $0.231(0.060)$ \\
\hline Sweden & $0.806(0.066)$ & $0.836(0.072)$ & $0.036(0.022)$ & $1.778(0.174)$ & $0.172(0.019)$ \\
\hline United Kingdom & $0.701(0.045)$ & $0.742(0.033)$ & $0.057(0.021)$ & $1.829(0.175)$ & $0.307(0.075)$ \\
\hline United States & $0.653(0.088)$ & $0.688(0.089)$ & $0.052(0.012)$ & 1.968 (0.149) & $0.287(0.07)$ \\
\hline Total & $0.619(0.152)$ & $0.664(0.156)$ & $0.068(0.044)$ & $1.814(0.40)$ & $0.225(0.090)$ \\
\hline $\begin{array}{l}\text { correlation with the } \\
\text { lagged minimum wage } \\
\text { measure }\end{array}$ & 0.042 & 0.155 & 0.508 & 0.773 & -0.716 \\
\hline \multicolumn{6}{|c|}{$\begin{array}{l}\text { Sources: The labor market indicators are taken from the OECD.Stat online data base. Fertility rates are from the OECD Family } \\
\text { data base. The wage gap is the difference between median male and female wages expressed as a percentage of the male median } \\
\text { wage. This variable is generated using OECD data. The mean wage ratio is used instead for the Netherlands, downloaded from } \\
\text { www.oecd.org/dataoecd/9/59/39606921.xls. The fertility rate and wage gap variables are standardized for the regressions. }\end{array}$} \\
\hline
\end{tabular}


Table 2b. Means (and Standard Deviations) of the Labor Market Institutions and Policy Variables

\begin{tabular}{lccccc}
\hline Country & $\begin{array}{c}\text { Labor Standards } \\
\text { Index }\end{array}$ & $\begin{array}{c}\text { Employment } \\
\text { Protection }\end{array}$ & $\begin{array}{c}\text { Active Labor } \\
\text { Market Policies }\end{array}$ & Union Density & $\begin{array}{c}\text { Unemployment } \\
\text { Insurance } \\
\text { Replacement Rate }\end{array}$ \\
\hline Australia & 3.0 & $0.335(0.048)$ & $5.685(0.667)$ & $5.468(9.443)$ & $23.123(3.368)$ \\
Belgium & 2.0 & $0.955(0.159)$ & $15.037(1.924)$ & $12.872(23.231)$ & $42.453(2.556)$ \\
Canada & 1.0 & $0.27(0.0)$ & $6.026(0.369)$ & $7.381(13.205)$ & $17.575(2.339)$ \\
Denmark & 2.0 & $0.655(0.146)$ & $24.579(6.306)$ & $25.96(34.846)$ & $50.105(8.053)$ \\
Finland & 3.0 & $0.733(0.043)$ & $15.407(5.129)$ & $17.986(32.488)$ & $30.98(7.488)$ \\
France & 3.0 & $0.929(0.105)$ & $10.038(1.48)$ & $2.318(4.07)$ & $33.823(6.257)$ \\
Germany & 4.0 & $0.970(0.128)$ & $18.76(4.02)$ & $5.37(9.493)$ & $28.45(1.101)$ \\
Ireland & 2.0 & $0.297(0.052)$ & $16.336(6.526)$ & $13.476(17.99)$ & $29.098(6.312)$ \\
Italy & 3.0 & $1.0495(0.235)$ & $11.11(0.533)$ & $7.949(14.138)$ & $13.195(14.448)$ \\
Japan & 1.0 & $0.677(0.049)$ & $4.787(1.120)$ & $4.683(8.306)$ & $9.9875(1.793)$ \\
Netherlands & 4.0 & $0.845(0.090)$ & $30.64(12.361)$ & $5.197(9.212)$ & $51.318(2.803)$ \\
New Zealand & 3.0 & $0.350(0.088)$ & $11.694(2.849)$ & $5.249(9.226)$ & $29.013(1.814)$ \\
Spain & 3.0 & $1.184(0.141)$ & $4.105(1.222)$ & $3.241(5.853)$ & $30.165(8.196)$ \\
Sweden & 5.0 & $0.889(0.268)$ & $48.715(19.133)$ & $18.185(32.658)$ & $23.855(6.379)$ \\
United Kingdom & 0.0 & $0.202(0.022)$ & $7.582(1.484)$ & $7.155(12.564)$ & $19.855(3.361)$ \\
United States & 0.0 & $0.070(0.000)$ & $3.587(0.349)$ & $2.949(5.17)$ & $12.86(1.301)$ \\
\hline Total & $2.434(1.37)$ & $0.651(0.359)$ & $14.63(13.15)$ & $9.09(19.02)$ & $27.87(13.32)$ \\
\hline correlation with the lagged & 0.658 & -0.119 & 0.436 & 0.031 & 0.711 \\
minimum wage measure & & & & & \\
Sources: The & & & &
\end{tabular}

Sources: The labor standards index is as described by Neumark and Wascher (2004: 237). It refers to the situation as of 1993 and is taken from the OECD Jobs Study (1994) and specifically excludes the contributions of minimum wages and employment protection policies. The employment protection variable is taken from Nickell (2006) and is the employment protection legislation data from the OECD.Stat using Version 1of that indicator: the strictness of employment protection legislation. Nickell (2006) extends this data using Blanchard and Wolfers (2000). These data are available only until 2004, with 2004 values being used for later years. The union density measure is again taken from Nickell (2006) and is calculated as union membership divided by employment, using administrative and survey data from the OECD labor market statistics data base. This base measure is then extended by splicing in data from Visser (2006). These data are available only until 2004, with 2004 values being used for later years. The unemployment insurance replacement rate is the original benefit replacement rate data published by the OECD. These data are also available only until 2004, with 2004 values again being used for later years. The active labor market policies variable is taken from Nickell (2006). It is calculated as expenditures divided by the unemployment rate. These data are available only until 2004; missing values are now interpolated using unemployment and GDP measures. All variables are standardized for the regressions. 
Table 3. Estimates of the Standard Minimum Wage Model Using International Data

\begin{tabular}{|c|c|c|c|c|c|c|c|c|c|}
\hline \multirow[t]{2}{*}{ Variable } & \multicolumn{3}{|c|}{$\begin{array}{l}\text { Adult Female Employment to } \\
\text { Population Ratio }\end{array}$} & \multicolumn{3}{|c|}{$\begin{array}{l}\text { Adult Female Unemployment } \\
\text { Rate }\end{array}$} & \multicolumn{3}{|c|}{$\begin{array}{l}\text { Adult Female Labor Force } \\
\text { Participation Rate (LFPR) }\end{array}$} \\
\hline & OLS & $\mathrm{FE}$ & GMM & OLS & FE & GMM & OLS & FE & GMM \\
\hline Lagged Adult Female Employment & & & $\begin{array}{c}0.687 * * * \\
(0.067)\end{array}$ & & & & & & \\
\hline Lagged Adult Female Unemployment Rate & & & & & & $\begin{array}{c}0.652 * * * \\
(0.099)\end{array}$ & & & \\
\hline Lagged Adult Female LFPR & & & & & & & & & $\begin{array}{c}0.708 * * * \\
(0.064)\end{array}$ \\
\hline Lagged Minimum to Median Wage Ratio & $\begin{array}{c}-0.277 * * * \\
(0.067)\end{array}$ & $\begin{array}{c}-0.107 * * * \\
(0.033)\end{array}$ & $\begin{array}{c}-0.056 * * * \\
(0.021)\end{array}$ & $\begin{array}{l}-0.025 \\
(0.023)\end{array}$ & $\begin{array}{c}0.034 \\
(0.035)\end{array}$ & $\begin{array}{l}0.035^{* *} \\
(0.014)\end{array}$ & $\begin{array}{c}-0.311^{* * *} \\
(0.068)\end{array}$ & $\begin{array}{c}-0.099 * * \\
(0.041)\end{array}$ & $\begin{array}{c}-0.035 * * \\
(0.017)\end{array}$ \\
\hline Adult Male Unemployment Rate & $\begin{array}{c}-0.609 * * * \\
(0.178)\end{array}$ & $\begin{array}{c}-0.641 * * * \\
(0.112)\end{array}$ & $\begin{array}{c}-0.358 * * * \\
(0.047)\end{array}$ & $\begin{array}{c}0.749 * * * \\
(0.078)\end{array}$ & $\begin{array}{c}0.701^{* * *} \\
(0.069)\end{array}$ & $\begin{array}{c}0.407 * * * \\
(0.085)\end{array}$ & $\begin{array}{l}-0.148 \\
(0.182)\end{array}$ & $\begin{array}{l}-0.208 \\
(0.140)\end{array}$ & $\begin{array}{l}-0.101^{*} \\
(0.060)\end{array}$ \\
\hline Wage Gap & $\begin{array}{l}-0.018 \\
(0.022)\end{array}$ & $\begin{array}{c}0.075^{* * *} \\
(0.016)\end{array}$ & $\begin{array}{l}0.02 * * \\
(0.008)\end{array}$ & $\begin{array}{l}-0.008 \\
(0.008)\end{array}$ & $\begin{array}{l}-0.02 * * \\
(0.009)\end{array}$ & $\begin{array}{l}-0.014 * \\
(0.007)\end{array}$ & $\begin{array}{l}-0.023 \\
(0.022)\end{array}$ & $\begin{array}{c}0.076^{* * *} \\
(0.018)\end{array}$ & $\begin{array}{c}0.014 \\
(0.009)\end{array}$ \\
\hline Fertility Rate & $\begin{array}{c}-0.582 * * * \\
(0.093)\end{array}$ & $\begin{array}{c}0.016 \\
(0.031)\end{array}$ & $\begin{array}{c}0.01 \\
(0.014)\end{array}$ & $\begin{array}{c}-0.129 * * * \\
(0.038)\end{array}$ & $\begin{array}{l}-0.029 \\
(0.044)\end{array}$ & $\begin{array}{l}-0.016 \\
(0.012)\end{array}$ & $\begin{array}{c}-0.668^{* * * *} \\
(0.097)\end{array}$ & $\begin{array}{c}0.011 \\
(0.036)\end{array}$ & $\begin{array}{c}0.001 \\
(0.014)\end{array}$ \\
\hline \multicolumn{10}{|c|}{ Lagged Minimum to Median Wage Ratio interacted with: } \\
\hline Wage Gap & $\begin{array}{l}-0.069 \\
(0.055)\end{array}$ & $\begin{array}{c}-0.167 * * * \\
(0.036)\end{array}$ & $\begin{array}{c}-0.041 * * \\
(0.017)\end{array}$ & $\begin{array}{c}0.016 \\
(0.017)\end{array}$ & $\begin{array}{l}0.043^{*} \\
(0.022)\end{array}$ & $\begin{array}{l}0.024 * \\
(0.014)\end{array}$ & $\begin{array}{l}-0.065 \\
(0.055)\end{array}$ & $\begin{array}{c}-0.169 * * \\
(0.043)\end{array}$ & $\begin{array}{l}-0.032 * \\
(0.017)\end{array}$ \\
\hline Fertility Rate & $\begin{array}{l}1.33 * * * \\
(0.173) \\
\end{array}$ & $\begin{array}{c}0.036 \\
(0.074) \\
\end{array}$ & $\begin{array}{c}-0.017 \\
(0.036) \\
\end{array}$ & $\begin{array}{c}0.125 \\
(0.072)^{+} \\
\end{array}$ & $\begin{array}{c}-0.024 \\
(0.079) \\
\end{array}$ & $\begin{array}{r}0.013 \\
(0.032) \\
\end{array}$ & $\begin{array}{c}1.437 * * * \\
(0.186) \\
\end{array}$ & $\begin{array}{c}-0.01 \\
(0.088) \\
\end{array}$ & $\begin{array}{l}-0.013 \\
(0.033) \\
\end{array}$ \\
\hline Constant & $\begin{array}{c}0.64 * * * \\
(0.039) \\
\end{array}$ & $\begin{array}{c}0.409 * * * \\
(0.021) \\
\end{array}$ & $\begin{array}{c}0.153^{* * *} \\
(0.025) \\
\end{array}$ & $\begin{array}{c}0.093^{* * *} \\
(0.014) \\
\end{array}$ & $\begin{array}{c}0.038 * * \\
(0.017) \\
\end{array}$ & $\begin{array}{c}0.003 \\
(0.012) \\
\end{array}$ & $\begin{array}{c}0.696 * * * \\
(0.039) \\
\end{array}$ & $\begin{array}{c}0.423 * * * \\
(0.026) \\
\end{array}$ & $\begin{array}{c}0.141^{* * *} \\
(0.023) \\
\end{array}$ \\
\hline Minimum Wage Elasticity & $\begin{array}{c}-0.455^{* *} \\
(0.219) \\
\end{array}$ & $\begin{array}{l}-0.103 \\
(0.071) \\
\end{array}$ & $\begin{array}{c}-0.051^{* * *} \\
(0.018) \\
\end{array}$ & $\begin{array}{c}-0.043^{* *} \\
(0.021) \\
\end{array}$ & $\begin{array}{l}0.035^{*} \\
(0.019) \\
\end{array}$ & $\begin{array}{c}0.032 * * * \\
(0.010) \\
\end{array}$ & $\begin{array}{c}-0.504^{* *} \\
(0.237) \\
\end{array}$ & $\begin{array}{l}-0.089 \\
(0.071) \\
\end{array}$ & $\begin{array}{c}-0.031 * * * \\
(0.013) \\
\end{array}$ \\
\hline Country Fixed Effects & NO & YES & YES & NO & YES & YES & NO & YES & YES \\
\hline Year Fixed Effects & YES & YES & YES & YES & YES & YES & YES & YES & YES \\
\hline Country Specific Time Trends & YES & YES & YES & YES & YES & YES & YES & YES & YES \\
\hline Observations & 340 & 340 & 319 & 340 & 340 & 319 & 340 & 340 & 319 \\
\hline R-squared & 0.889 & 0.985 & & 0.881 & 0.886 & & 0.881 & 0.985 & \\
\hline
\end{tabular}


Table 4: Estimates of the Augmented Minimum Wage Model with Characteristics of Minimum Wage Systems and Other Labor Market Policies and Institutions

\begin{tabular}{|c|c|c|c|c|c|c|c|c|c|}
\hline \multirow[t]{2}{*}{ Variable } & \multicolumn{3}{|c|}{$\begin{array}{l}\text { Adult Female Employment to } \\
\text { Population Ratio }\end{array}$} & \multicolumn{3}{|c|}{ Adult Female Unemployment Rate } & \multicolumn{3}{|c|}{$\begin{array}{l}\text { Adult Female Labor Force } \\
\text { Participation Rate (LFPR) }\end{array}$} \\
\hline & OLS & $\mathrm{FE}$ & GMM & OLS & FE & GMM & OLS & $\mathrm{FE}$ & GMM \\
\hline Lagged Adult Female Employment & & & $\begin{array}{c}0.638 * * * \\
(0.067)\end{array}$ & & & & & & \\
\hline Lagged Adult Female Unemployment Rate & & & & & & $\begin{array}{c}0.564 * * * \\
(0.082)\end{array}$ & & & \\
\hline Lagged Adult Female LFPR & & & & & & & & & $\begin{array}{c}0.68 * * * \\
(0.06)\end{array}$ \\
\hline Lagged Minimum to Median Wage Ratio & $\begin{array}{c}-0.838 * * * \\
(0.183)\end{array}$ & $\begin{array}{c}-0.271^{* *} \\
(0.120)\end{array}$ & $\begin{array}{c}-0.249 * * * \\
(0.046)\end{array}$ & $\begin{array}{l}-0.044 \\
(0.076)\end{array}$ & $\begin{array}{l}-0.096 \\
(0.084)\end{array}$ & $\begin{array}{c}0.04 \\
(0.035)\end{array}$ & $\begin{array}{c}-0.917 * * * \\
(0.185)\end{array}$ & $\begin{array}{c}-0.344^{* *} \\
(0.120)\end{array}$ & $\begin{array}{c}-0.204^{* * *} \\
(0.056)\end{array}$ \\
\hline Adult Male Unemployment Rate & $\begin{array}{c}-0.811 * * * \\
(0.121)\end{array}$ & $\begin{array}{c}-0.535 * * * \\
(0.103)\end{array}$ & $\begin{array}{c}-0.359 * * * \\
(0.045)\end{array}$ & $\begin{array}{c}0.806 * * * \\
(0.077)\end{array}$ & $\begin{array}{c}0.635 * * * \\
(0.087)\end{array}$ & $\begin{array}{c}0.425^{* * *} \\
(0.082)\end{array}$ & $\begin{array}{c}-0.367 * * * \\
(0.108)\end{array}$ & $\begin{array}{l}-0.157 \\
(0.148)\end{array}$ & $\begin{array}{l}-0.109 \\
(0.071)\end{array}$ \\
\hline Wage Gap & $\begin{array}{l}-0.007 \\
(0.030)\end{array}$ & $\begin{array}{c}0.062^{* *} \\
(0.024)\end{array}$ & $\begin{array}{c}0.028 * * * \\
(0.010)\end{array}$ & $\begin{array}{c}0.063^{* * *} \\
(0.016)\end{array}$ & $\begin{array}{c}0.009 \\
(0.024)\end{array}$ & $\begin{array}{c}-0.01 \\
(0.009)\end{array}$ & $\begin{array}{c}0.029 \\
(0.030)\end{array}$ & $\begin{array}{c}0.079 * * \\
(0.033)\end{array}$ & $\begin{array}{l}0.023^{*} \\
(0.014)\end{array}$ \\
\hline Fertility Rate & $\begin{array}{c}-0.151^{* * * *} \\
(0.056)\end{array}$ & $\begin{array}{l}-0.051 \\
(0.046)\end{array}$ & $\begin{array}{l}-0.032^{*} \\
(0.017)\end{array}$ & $\begin{array}{c}-0.114^{* * *} \\
(0.031)\end{array}$ & $\begin{array}{l}0.008 \\
(0.034)\end{array}$ & $\begin{array}{c}0.009 \\
(0.015)\end{array}$ & $\begin{array}{c}-0.19 * * * \\
(0.055)\end{array}$ & $\begin{array}{l}-0.035 \\
(0.038)\end{array}$ & $\begin{array}{l}-0.024 \\
(0.015)\end{array}$ \\
\hline Dummy-Bargained Minimum Wage & $\begin{array}{c}0.309 * * * \\
(0.063)\end{array}$ & $\begin{array}{l}0.217^{* *} \\
(0.083)\end{array}$ & & $\begin{array}{c}-0.14 * * * \\
(0.032)\end{array}$ & $\begin{array}{l}-0.102 \\
(0.075)\end{array}$ & & $\begin{array}{c}0.266 * * * \\
(0.065)\end{array}$ & $\begin{array}{l}0.169 * \\
(0.095)\end{array}$ & \\
\hline Dummy-Youth Subminimum & $\begin{array}{c}-0.388 * * * \\
(0.109)\end{array}$ & & & $\begin{array}{c}0.063 \\
(0.047)\end{array}$ & & & $\begin{array}{c}-0.404^{* * *} \\
(0.108)\end{array}$ & & \\
\hline Dummy-Subnational Minimum & $\begin{array}{c}0.085 \\
(0.113)\end{array}$ & & & $\begin{array}{l}-0.024 \\
(0.059)\end{array}$ & & & $\begin{array}{c}0.123 \\
(0.112)\end{array}$ & & \\
\hline Employment Protection Index & $\begin{array}{c}-0.183^{* * *} \\
(0.029)\end{array}$ & $\begin{array}{c}-0.052 \\
(0.056)\end{array}$ & $\begin{array}{c}-0.034 \\
(0.025)\end{array}$ & $\begin{array}{c}0.046^{* * *} \\
(0.018)\end{array}$ & $\begin{array}{c}0.046 \\
(0.050)\end{array}$ & $\begin{array}{l}0.027 * \\
(0.014)\end{array}$ & $\begin{array}{c}-0.18 * * * \\
(0.029)\end{array}$ & $\begin{array}{c}-0.051 \\
(0.069)\end{array}$ & $\begin{array}{c}-0.03 \\
(0.023)\end{array}$ \\
\hline Union Density & $\begin{array}{c}0.03 \\
(0.028)\end{array}$ & $\begin{array}{l}-0.023 \\
(0.022)\end{array}$ & $\begin{array}{l}-0.003 \\
(0.007)\end{array}$ & $\begin{array}{c}0.031^{* *} \\
(0.012)\end{array}$ & $\begin{array}{c}0.031 \\
(0.020)\end{array}$ & $\begin{array}{c}0.004 \\
(0.009)\end{array}$ & $\begin{array}{c}0.059 * * \\
(0.025)\end{array}$ & $\begin{array}{c}0.007 \\
(0.022)\end{array}$ & $\begin{array}{c}0.000 \\
(0.011)\end{array}$ \\
\hline Unemployment Insurance Replacement Rate & $\begin{array}{c}0.015 \\
(0.037)\end{array}$ & $\begin{array}{c}-0.106^{* *} \\
(0.043)\end{array}$ & $\begin{array}{c}-0.076^{* * *} \\
(0.016)\end{array}$ & $\begin{array}{c}0.064^{* * *} \\
(0.019)\end{array}$ & $\begin{array}{c}0.04 \\
(0.027)\end{array}$ & $\begin{array}{c}0.026^{* * * *} \\
(0.007)\end{array}$ & $\begin{array}{c}0.07^{*} \\
(0.036)\end{array}$ & $\begin{array}{l}-0.049 \\
(0.042)\end{array}$ & $\begin{array}{c}-0.048 * * * \\
(0.012)\end{array}$ \\
\hline Active Labor Market Policies & $\begin{array}{l}-0.001 \\
(0.023)\end{array}$ & $\begin{array}{c}0.000 \\
(0.018)\end{array}$ & $\begin{array}{c}-0.01 \\
(0.006)\end{array}$ & $\begin{array}{l}-0.015 \\
(0.013)\end{array}$ & $\begin{array}{l}-0.012 \\
(0.009)\end{array}$ & $\begin{array}{c}0.002 \\
(0.005)\end{array}$ & $\begin{array}{l}-0.018 \\
(0.021)\end{array}$ & $\begin{array}{l}-0.016 \\
(0.019)\end{array}$ & $\begin{array}{c}-0.01 \\
(0.009)\end{array}$ \\
\hline Labor Standards Index & $\begin{array}{c}0.332^{* * *} \\
(0.045)\end{array}$ & & & $\begin{array}{c}0.052 * * \\
(0.024)\end{array}$ & & & $\begin{array}{c}0.398 * * * \\
(0.043)\end{array}$ & & \\
\hline
\end{tabular}


continues from the previous page

\begin{tabular}{|c|c|c|c|c|c|c|c|c|c|}
\hline \multicolumn{10}{|c|}{ Lagged Minimum to Median Wage Ratio interacted with: } \\
\hline Wage Gap & $\begin{array}{c}-0.119^{* *} \\
(0.060)\end{array}$ & $\begin{array}{c}-0.134^{* *} \\
(0.055)\end{array}$ & $\begin{array}{c}-0.059 * * \\
(0.023)\end{array}$ & $\begin{array}{c}-0.118^{* * *} \\
(0.033)\end{array}$ & $\begin{array}{l}-0.028 \\
(0.051)\end{array}$ & $\begin{array}{c}0.013 \\
(0.021)\end{array}$ & $\begin{array}{c}-0.195^{* * *} \\
(0.061)\end{array}$ & $\begin{array}{c}-0.179 * * \\
(0.078)\end{array}$ & $\begin{array}{l}-0.053^{*} \\
(0.030)\end{array}$ \\
\hline Fertility Rate & $\begin{array}{c}0.367 * * * \\
(0.111)\end{array}$ & $\begin{array}{c}0.114 \\
(0.118)\end{array}$ & $\begin{array}{c}0.042 \\
(0.042)\end{array}$ & $\begin{array}{l}0.112 * \\
(0.061)\end{array}$ & $\begin{array}{l}-0.064 \\
(0.071)\end{array}$ & $\begin{array}{c}-0.03 \\
(0.033)\end{array}$ & $\begin{array}{c}0.383^{* * *} \\
(0.112)\end{array}$ & $\begin{array}{c}0.05 \\
(0.104)\end{array}$ & $\begin{array}{c}0.02 \\
(0.037)\end{array}$ \\
\hline Dummy-Bargained Minimum Wage & $\begin{array}{c}-0.589 * * * \\
(0.138)\end{array}$ & $\begin{array}{c}-0.545^{* *} \\
(0.214)\end{array}$ & $\begin{array}{c}-0.383 * * * \\
(0.107)\end{array}$ & $\begin{array}{c}0.297 * * * \\
(0.071)\end{array}$ & $\begin{array}{c}0.229 \\
(0.183)\end{array}$ & $\begin{array}{c}0.177^{* *} \\
(0.082)\end{array}$ & $\begin{array}{c}-0.484^{* * *} \\
(0.144)\end{array}$ & $\begin{array}{l}-0.445^{*} \\
(0.240)\end{array}$ & $\begin{array}{c}-0.277 * * \\
(0.131)\end{array}$ \\
\hline Dummy-Youth Subminimum? & $\begin{array}{c}0.718^{* * *} \\
(0.212)\end{array}$ & $\begin{array}{c}0.196 \\
(0.167)\end{array}$ & $\begin{array}{c}0.162 * * \\
(0.071)\end{array}$ & $\begin{array}{l}-0.107 \\
(0.089)\end{array}$ & $\begin{array}{l}-0.024 \\
(0.100)\end{array}$ & $\begin{array}{l}-0.046 \\
(0.053)\end{array}$ & $\begin{array}{c}0.742^{* * *} \\
(0.211)\end{array}$ & $\begin{array}{c}0.239 \\
(0.178)\end{array}$ & $\begin{array}{c}0.146 * * \\
(0.070)\end{array}$ \\
\hline Dummy-Subnational Minimum? & $\begin{array}{c}0.209 \\
(0.215)\end{array}$ & $\begin{array}{c}0.41 * \\
(0.213)\end{array}$ & $\begin{array}{c}0.345^{* * *} \\
(0.071)\end{array}$ & $\begin{array}{l}-0.018 \\
(0.115)\end{array}$ & $\begin{array}{l}-0.048 \\
(0.144)\end{array}$ & $\begin{array}{c}-0.109 * * \\
(0.051)\end{array}$ & $\begin{array}{c}0.125 \\
(0.216)\end{array}$ & $\begin{array}{c}0.287 \\
(0.176)\end{array}$ & $\begin{array}{c}0.226 * * * \\
(0.077)\end{array}$ \\
\hline Employment Protection Index & $\begin{array}{c}0.259 * * * \\
(0.058)\end{array}$ & $\begin{array}{c}0.104 \\
(0.105)\end{array}$ & $\begin{array}{c}0.063 \\
(0.045)\end{array}$ & $\begin{array}{l}-0.063^{*} \\
(0.033)\end{array}$ & $\begin{array}{l}-0.084 \\
(0.098)\end{array}$ & $\begin{array}{c}-0.047^{*} \\
(0.027)\end{array}$ & $\begin{array}{c}0.258 * * * \\
(0.058)\end{array}$ & $\begin{array}{c}0.093 \\
(0.134)\end{array}$ & $\begin{array}{c}0.054 \\
(0.042)\end{array}$ \\
\hline Union Density & $\begin{array}{l}-0.075 \\
(0.049)\end{array}$ & $\begin{array}{c}0.032 \\
(0.035)\end{array}$ & $\begin{array}{l}-0.007 \\
(0.013)\end{array}$ & $\begin{array}{l}-0.032 \\
(0.023)\end{array}$ & $\begin{array}{l}-0.045 \\
(0.040)\end{array}$ & $\begin{array}{c}0.004 \\
(0.018)\end{array}$ & $\begin{array}{c}-0.116^{* *} \\
(0.046)\end{array}$ & $\begin{array}{l}-0.016 \\
(0.042)\end{array}$ & $\begin{array}{l}-0.006 \\
(0.022)\end{array}$ \\
\hline Unemployment Insurance Replacement Rate & $\begin{array}{l}-0.088 \\
(0.070)\end{array}$ & $\begin{array}{l}0.166^{* *} \\
(0.077)\end{array}$ & $\begin{array}{c}0.139 * * * \\
(0.032)\end{array}$ & $\begin{array}{c}-0.074^{* *} \\
(0.033)\end{array}$ & $\begin{array}{l}-0.006 \\
(0.064)\end{array}$ & $\begin{array}{l}-0.019 \\
(0.019)\end{array}$ & $\begin{array}{l}-0.16^{* *} \\
(0.070)\end{array}$ & $\begin{array}{c}0.096 \\
(0.072)\end{array}$ & $\begin{array}{c}0.102^{* * *} \\
(0.033)\end{array}$ \\
\hline Active Labor Market Policies & $\begin{array}{c}0.027 \\
(0.042)\end{array}$ & $\begin{array}{c}0.014 \\
(0.035)\end{array}$ & $\begin{array}{l}0.026^{* *} \\
(0.013)\end{array}$ & $\begin{array}{c}0.025 \\
(0.024)\end{array}$ & $\begin{array}{c}0.016 \\
(0.019)\end{array}$ & $\begin{array}{l}-0.007 \\
(0.010)\end{array}$ & $\begin{array}{c}0.058 \\
(0.038)\end{array}$ & $\begin{array}{c}0.041 \\
(0.037)\end{array}$ & $\begin{array}{c}0.024 \\
(0.019)\end{array}$ \\
\hline Labor Standards Index & $\begin{array}{c}-0.522 * * * \\
(0.082)\end{array}$ & $\begin{array}{l}-0.055 \\
(0.122)\end{array}$ & $\begin{array}{l}-0.088^{*} \\
(0.053)\end{array}$ & $\begin{array}{c}-0.156^{* * *} \\
(0.044)\end{array}$ & $\begin{array}{l}-0.075 \\
(0.096)\end{array}$ & $\begin{array}{c}-0.003 \\
(0.033)\end{array}$ & $\begin{array}{c}-0.675^{* * *} \\
(0.078)\end{array}$ & $\begin{array}{l}-0.169 \\
(0.149)\end{array}$ & $\begin{array}{l}-0.113^{*} \\
(0.060)\end{array}$ \\
\hline Constant & $\begin{array}{c}0.803^{* * *} \\
(0.081)\end{array}$ & $\begin{array}{c}0.344^{* * *} \\
(0.056) \\
\end{array}$ & $\begin{array}{c}0.165^{* * *} \\
(0.055) \\
\end{array}$ & $\begin{array}{c}0.11^{* * *} \\
(0.034)\end{array}$ & $\begin{array}{l}0.119^{* *} \\
(0.045)\end{array}$ & $\begin{array}{c}0.03^{*} \\
(0.016) \\
\end{array}$ & $\begin{array}{l}0.88^{* * *} \\
(0.082)\end{array}$ & $\begin{array}{c}0.411^{* * *} \\
(0.055) \\
\end{array}$ & $\begin{array}{c}0.157^{* * *} \\
(0.051) \\
\end{array}$ \\
\hline Minimum Wage Elasticity & $\begin{array}{c}-0.689 * * * \\
(0.208)\end{array}$ & $\begin{array}{l}-0.209 * \\
(0.112)\end{array}$ & $\begin{array}{c}-0.174 * * * \\
(0.072)\end{array}$ & $\begin{array}{l}-0.029 \\
(0.122)\end{array}$ & $\begin{array}{l}-0.056 \\
(0.062)\end{array}$ & $\begin{array}{l}0.033 \\
(0.02)\end{array}$ & $\begin{array}{c}-0.751 * * * \\
(0.262)\end{array}$ & $\begin{array}{c}-0.260 * * * \\
(0.095)\end{array}$ & $\begin{array}{c}-0.142^{* * *} \\
(0.058)\end{array}$ \\
\hline Country Fixed Effects & NO & YES & YES & NO & YES & YES & NO & YES & YES \\
\hline $\begin{array}{l}\text { Year Fixed Effects } \\
\text { Country Specific Time Trends }\end{array}$ & $\begin{array}{l}\text { YES } \\
\text { YES }\end{array}$ & $\begin{array}{l}\text { YES } \\
\text { YES }\end{array}$ & $\begin{array}{l}\text { YES } \\
\text { YES }\end{array}$ & $\begin{array}{l}\text { YES } \\
\text { YES }\end{array}$ & $\begin{array}{l}\text { YES } \\
\text { YES }\end{array}$ & $\begin{array}{l}\text { YES } \\
\text { YES }\end{array}$ & $\begin{array}{l}\text { YES } \\
\text { YES }\end{array}$ & $\begin{array}{l}\text { YES } \\
\text { YES }\end{array}$ & $\begin{array}{l}\text { YES } \\
\text { YES }\end{array}$ \\
\hline Observations & 339 & 339 & 319 & 339 & 339 & 319 & 339 & 339 & 319 \\
\hline R-squared & 0.975 & 0.989 & & 0.951 & 0.923 & & 0.972 & 0.987 & \\
\hline Number of Countries & & 16 & 14 & & 16 & 14 & & 16 & 14 \\
\hline Hausman / Sargan tests (p-values) & 0.000 & 0.000 & 1.000 & 0.000 & 0.001 & 1.000 & 0.000 & 0.000 & 1.000 \\
\hline
\end{tabular}


Table 5. Minimum Wage Elasticity of Labor Market Indicators

\begin{tabular}{lllllll}
\hline & \multicolumn{3}{c}{ Mean Minimum Wage Elasticity (and Standard Deviation) } \\
\cline { 2 - 7 } Country & \multicolumn{3}{c}{ Employment } & \multicolumn{2}{c}{ Unemployment } & \multicolumn{2}{c}{$\begin{array}{c}\text { Labor Force } \\
\text { Participation }\end{array}$} \\
\hline Australia & -0.206 & $(0.015)$ & 0.039 & $(0.004)$ & -0.166 & $(0.012)$ \\
Belgium & -0.223 & $(0.014)$ & 0.084 & $(0.009)$ & -0.147 & $(0.013)$ \\
Canada & -0.154 & $(0.016)$ & 0.032 & $(0.003)$ & -0.127 & $(0.016)$ \\
France & -0.177 & $(0.057)$ & 0.012 & $(0.013)$ & -0.154 & $(0.045)$ \\
Germany & -0.301 & $(0.011)$ & 0.061 & $(0.003)$ & -0.276 & $(0.011)$ \\
Ireland & -0.083 & $(0.014)$ & 0.025 & $(0.002)$ & -0.056 & $(0.013)$ \\
Italy & -0.420 & $(0.026)$ & 0.077 & $(0.003)$ & -0.339 & $(0.019)$ \\
Japan & -0.206 & $(0.003)$ & 0.028 & $(0.003)$ & -0.167 & $(0.003)$ \\
Netherlands & -0.055 & $(0.013)$ & -0.013 & $(0.006)$ & -0.067 & $(0.010)$ \\
New Zealand & -0.175 & $(0.022)$ & 0.029 & $(0.009)$ & -0.145 & $(0.020)$ \\
Spain & -0.146 & $(0.014)$ & 0.009 & $(0.005)$ & -0.117 & $(0.012)$ \\
Sweden & -0.156 & $(0.040)$ & 0.000 & $(0.014)$ & -0.161 & $(0.032)$ \\
United Kingdom & -0.167 & $(0.080)$ & 0.067 & $(0.037)$ & -0.110 & $(0.061)$ \\
United States & -0.170 & $(0.011)$ & 0.043 & $(0.005)$ & -0.130 & $(0.009)$ \\
\hline
\end{tabular}


Table 6. Elasticities By Labor Market Characteristics

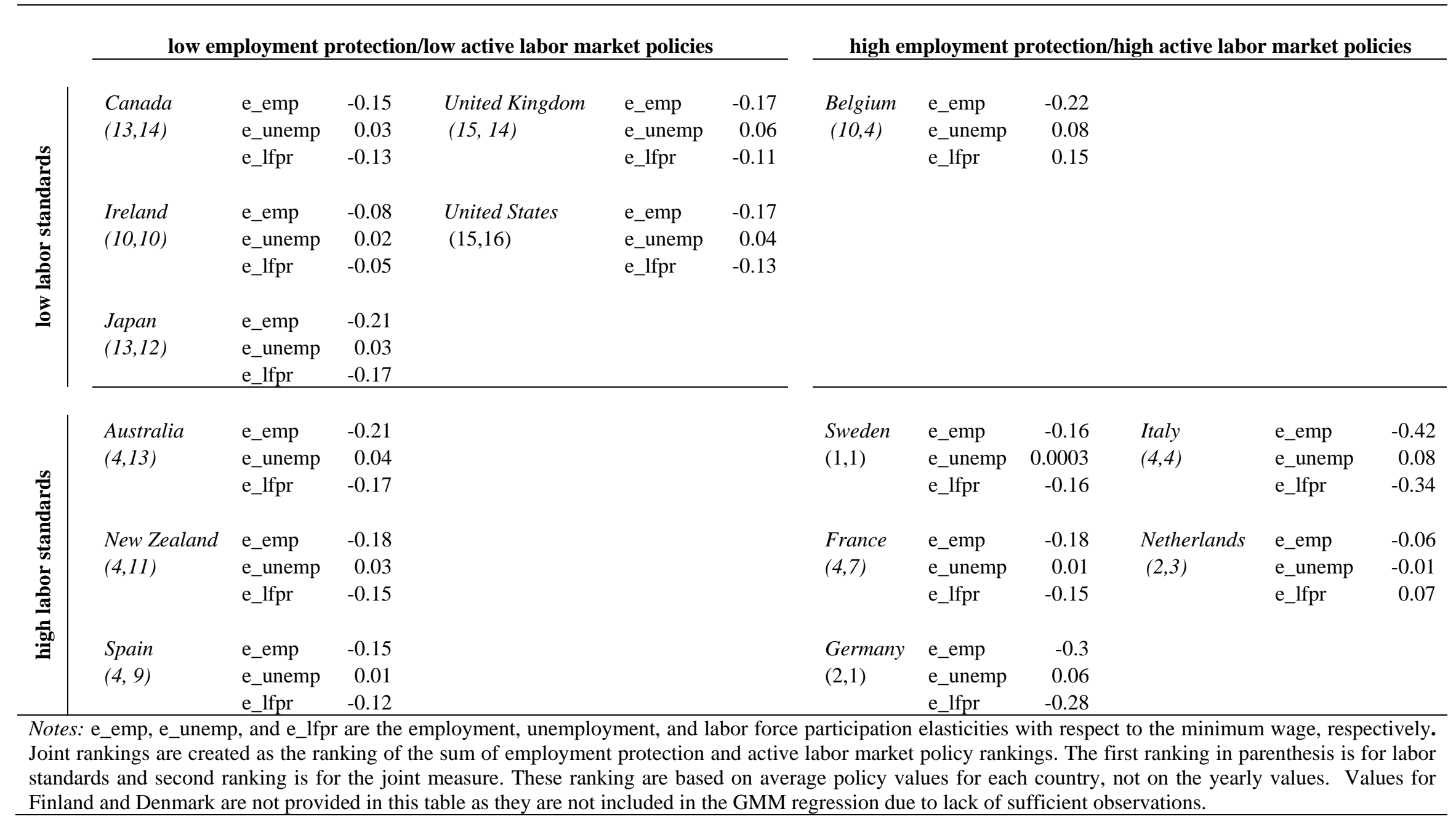


Table 7. Elasticities By Labor Market Policies and Social Characteristics

\begin{tabular}{|c|c|c|c|c|c|c|}
\hline \multirow{8}{*}{ 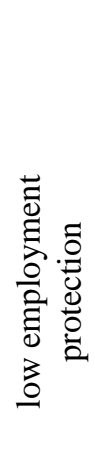 } & \multirow{5}{*}{ 莫总 } & & \multicolumn{2}{|c|}{ low labor standards } & \multicolumn{2}{|c|}{ high labor standards } \\
\hline & & & low wage gap & high wage gap & low wage gap & high wage gap \\
\hline & & e_emp & -0.098 & -0.186 & -0.200 & -0.213 \\
\hline & & e_unemp & 0.024 & 0.052 & 0.038 & 0.039 \\
\hline & & e_lfpr & -0.072 & -0.142 & -0.161 & -0.177 \\
\hline & 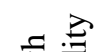 & e_emp & -0.113 & -0.176 & -0.173 & -0.199 \\
\hline & 可 & e_unemp & 0.028 & 0.047 & 0.027 & 0.035 \\
\hline & & e_lfpr & -0.082 & -0.135 & -0.142 & -0.169 \\
\hline & & e_emp & -0.223 & -0.206 & -0.167 & -0.161 \\
\hline & 定恶 & e_unemp & 0.084 & 0.026 & 0.012 & 0.016 \\
\hline ్ㅗㅇ. & & e_lfpr & -0.147 & -0.168 & -0.149 & -0.152 \\
\hline 흘 & & e_emp & & & -0.140 & -0.274 \\
\hline .00 & 可 & e_unemp & & & -0.002 & 0.034 \\
\hline & & e_lfpr & & & -0.138 & -0.233 \\
\hline $\begin{array}{l}\text { Notes: } \\
\text { elastici } \\
\text { each li } \\
\text { country } \\
\text { charact } \\
\text { Values } \\
\text { regress }\end{array}$ & np, & $\begin{array}{l}\text { unemp, a } \\
\text { espect to t } \\
\text { t policy o } \\
\text { ne sample } \\
\text { ccordingly } \\
\text { nd and De } \\
\text { lack of suf }\end{array}$ & $\begin{array}{l}\text { e_lfpr are the } \\
\text { ninimum wage, } \\
\text { cial characterist } \\
\text { od but unique } \\
\text { sticities for one } \\
\text { ark are not pro } \\
\text { nt observations. }\end{array}$ & $\begin{array}{l}\text { oyment, unemp } \\
\text { ectively. In th } \\
\text { e based on yea } \\
\text { ach country an } \\
\text { try for different } \\
\text { in this table }\end{array}$ & $\begin{array}{l}\text { ent, and labor } \\
\text { le high and lo } \\
\text { alues, not a un } \\
\text { ch year given } \\
\text { s can be averag } \\
\text { ey are not inc }\end{array}$ & $\begin{array}{l}\text { ce participation } \\
\text { assifications for } \\
\text { value for each } \\
\text { values of these } \\
\text { a different cells. } \\
\text { d in the GMM }\end{array}$ \\
\hline
\end{tabular}




\section{References}

Addison, John T., McKinley L. Blackburn, and Chad D. Cotti. 2011. "The Effect of Minimum Wages on Labor Market Outcomes: County-Level Estimates from the Restaurant-and-Bar Sector.” British Journal of Industrial Relations (forthcoming).

Addison, John T., and Paulino Teixeira. 2003. “The Economics of Employment Protection.” Journal of Labor Research, Vol. 24, No. 1, pp. 85-128.

Arellano, Manuel, and Stephen Bond. 1981. "Some Tests of Specification for Panel Data: MonteCarlo Evidence and an Application to Employment Equations.” Review of Econopmic studies, Vol. 58, No. 2, pp. 277-97.

Blanchard, Olivier, and Justin Wolfers. 2000. "The Role of Shocks and Institutions in the Rise of European Unemployment: The Aggregate Evidence.” Economic Journal, Vol. 110, No. 462, pp. C1-C33.

Boockmann, Bernhard. 2010. “The Combined Employment Effects of Minimum Wages and Labor market regulation: A Meta-Analysis.” IZA Discussion Paper No. 4983. Bonn: Institute for the Study of Labor/Forschungsinstitut zur Zukunft der Arbeit.

Card, David, and Alan B. Krueger. 1994. "Minimum Wages and Employment: A Case study of the Fast-Food Industry in New Jersey and Pennsylvania.” American Economic Review, Vol. 85, No. 5, pp. 772-93.

Card, David, and Alan B. Krueger.1995. “Time-Series Minimum Wage Studies: A Meta-Analysis.” American Economic Review, Vol. 85, No, 2, pp. 238-43.

Coe, David T., and Dennis J. Snower. 1997. "Policy Complementarities. The Case for Fundamental Labor Market Reform.” IMF Staff Papers, Vol. 44, No. 1, pp. 1-35.

Cahuc, Pierre, and Andre Zylberberg. 1999. "Job Protection, Minimum Wage and Unemployment.” IZA Discussion Paper No. 95. Bonn: Institute for the Study of Labor/Forschungsinstitut zur Zukunft der Arbeit.

Dolado, Juan, Francis Kramarz, Stephen Machin, Alan Manning, David Margolis, and Coen Teulings. 1996. “The Economic Impact of Minimum wages in Europe.” Economic Policy, Vol. 23, (October), pp. 319-70.

Hausman, Jerry A., and William E. Taylor. 1981. "Panel Data and Unobservable Individual Effects.” Econometrica, Vol. 49, No. 6, pp. 1377-98.

Lazear, Edward P. 1990. "Job Security Provisons and Employment." Quarterly Journal of Economics, Vol. 105, No. 3, pp. 699-726.

Neumark, David, and William Wascher. 1992. "Employment Effects of Minimum and Subminimum Wages: Panel Data on State Minimum Wage Laws.” Industrial and Labor Relations Review, Vol. 46, No. 1, pp. 55-81. 
Neumark, David, and William Wascher. 2004. "Minimum Wages, Labor Market Institutions, and Youth Employment: A Cross-National Analysis.” Industrial and Labor Relations Review, Vol. 57, No. 2, pp. 223-48.

Neumark, David, and William Wascher. 2007. “Minimum Wages and Employment.” IZA Discussion Paper No. 2750. Bonn: Institute for the Study of Labor/Forschungsinstitut zur Zukunft der Arbeit.

Nickell, Stephen, and Richard Layard. 1999. Labor market institutions and Economic Performance.” In Orley Ashenfelter and David Card, eds., Handbook of Labor Economics, Vol. 3. New York: Elsevier, pp. 3029-3084.

Nickell, Stephen, Luca Nunziata, and Wolfgang Ochel. 2005. "Unemployment in the OECD since the 1960s. What do We Know?” Economic Journal, Vol. 115: 500, pp. 1-27.

Nickell, William. 2006. “The CEP-OECD Institutions Data Set (1960-2004).” CEP Discussion Paper No. 759. London: Centre for Economic Performance, London School of Economics and Political Science.

Organisation for Economic Co-operation and Development. 1994. The OECD Jobs Study: Evidence and Explanations. Part II: The Adjustment Potential of the Labour Market. Paris: OECD.

Organisation for Economic Co-operation and Development. 1998. "Making the Most Out of the Minimum: Statutory Minimum Wages, Employment and Poverty. Employment Outlook, Chapter 2. Paris: OECD, pp. 31-79.

Ozturk, Orgul Demet. 2006. "Employment Effects of Minimum Wages in Markets with Fixed Employment Costs.” Unpublished manuscript, University of Wisconsin-Madison.

Scarpetta, Stephano. 1996. "Assessing the Role of Labor Market Policies and Institutional Settings on Unemployment: A Cross-Section Study.” OECD Economic Studies, No. 26, pp. 43-98.

Siebert, Horst. 1997. “Labor Market Rigidities: At the Root of Unemployment in Europe.” Journal of Economic Perspectives, Vol. 11, No. 1, pp. 37-54.

Visser, Jelle. 2006. “Union Membership Statistics in 24 Countries.” Monthly Labor Review, Vol. 129, No. 1, pp. 38-49. 